\title{
COMPATIBLE ORGANIZATIONAL STRUCTURE WITH KNOWLEDGE MANAGEMENT: A CASE STUDY IN A METALLURGY INDUSTRY
}

\section{ESTRUTURA ORGANIZACIONAL COMPATÍVEL COM A GESTÃO DO CONHECIMENTO: UM ESTUDO DE CASO EM UMA INDÚSTRIA METALÚRGICA}

\author{
Paula Michelle Purcidonio ${ }^{1}$, Prof. Dr. Antonio Carlos de Francisco ${ }^{1}$, \\ Antonella Carvalho de Oliveira ${ }^{1}$ \\ ${ }^{1}$ Universidade Tecnológica Federal do Paraná - Campus Ponta Grossa \\ Recebido para publicação em 15/05/2007 \\ Aceito para publicação em 07/12/2007
}

\begin{abstract}
This article has as its main objective to identify the elements of knowledge management within the scope of the organizational structure of a metallurgy industry. In order to reach the proposed objective, a qualitative research with a case study was carried out in a metallurgy industry of the city of Ponta Grossa. The data were collected through a semi-structured interview. The research evinced a top-down organizational structure in which the upper management creates the basic concepts so that the lower levels can implement them. However, this structure is inefficient in stimulating the necessary dynamic interaction for the creation of the organizational knowledge. As to the organizational structure compatible with knowledge management in the company, the data show a deficiency in team work, with little delegation of responsibilities. This metallurgy industry must, therefore, try to strengthen other elements in the organizational structure, implanting a more flexible and agile organizational structure in order to be able to react to market changes.
\end{abstract}

Keywords: Knowledge management. Organizational structure. Metallurgic industry.

\section{RESUMO}

Este artigo tem, como objetivo principal, identificar os elementos da gestão do conhecimento no âmbito da estrutura organizacional de uma indústria metalúrgica. A fundamentação teórica está alicerçada na revisão da literatura existente sobre a gestão do conhecimento. Entre os itens abordados, estão a conceituação e a diferenciação entre dado, informação, conhecimento, competência, tipos de conhecimento, gestão do conhecimento e estrutura organizacional. Para atingir o objetivo proposto, efetuou-se pesquisa qualitativa, com um estudo de caso, realizado em uma 
indústria metalúrgica da cidade de Ponta Grossa. Os dados foram coletados através de entrevista semi-estruturada; tendo-se constatado uma estrutura organizacional top-down (de-cima-para-baixo), com a alta gerência criando os conceitos básicos, para os níveis inferiores poderem implementá-los; essa estrutura, porém, parece ineficaz, quando se trata de estimular a interação dinâmica necessária para criar o conhecimento organizacional. Quanto à estrutura organizacional, compatível com a gestão do conhecimento na empresa, os dados mostram deficiência no trabalho em equipe, com pouca delegação de responsabilidades. Concluindo, a pesquisa revela que a indústria metalúrgica deve buscar fortalecer outros elementos na estrutura organizacional, buscando implantar uma estrutura organizacional com maior flexibilidade para se tornar mais ágil, e assim, reagir adequadamente às mudanças do mercado.

Palavras-chave: Gestão do conhecimento. Estrutura organizacional. Indústria metalúrgica.

\section{Introduction}

Knowledge Management (KM) is, in the organizational management, an area that has received increasing attention; ecause this is the era of knowledge, in which the creation and management of knowledge have become the central aspect of decisions and economic growth. For Drucker apud Nonaka \& Takeuchi (1997, p. 5), "in the new economy knowledge is not only one more resource, along the traditional production factors, work, capital and land, but the only significant resource currently".

Corroborating with the above-mentioned idea, Terra (2000, p. 1) affirms that the main input of workers is not the physical effort anymore, but the capacity to create, to learn and to develop new concepts, products and services based strictly in knowledge”. Muller \& Grings (2003) assert that the competitive factor is knowledge and the abilities of people in each organization; thus, many organizations have realized the importance of easy systematic actions to identifying, developing, sharing, using and holding back knowledge. For Terra (2000), KM must be related to seven dimensions that evaluate the existence of action, values, rules and compatible mechanisms with the implantation of a management systems process that involves three different levels of the managerial practice: the strategic, the organizational and the structural ones.

In this context, this article has as its main objective to identify the elements of KM within the scope of the organizational structure of a metallurgic industry. The methodology approach used in this article was a qualitative and an exploratory research, with a study case undertaken in a metallurgic industry of the city of Ponta Grossa. The data were collected via semi-structured interview and bibliographical research. The anonymity of the studied metallurgic industry was kept; however, along this article, it will be called "Alpha” company.

\section{Theoretical fundamentation}

\subsection{Data, information and knowledge}

In order to put $\mathrm{KM}$, in a context, it is necessary to approach the concepts of data, information and knowledge, therefore these terms give support to the subject and to the implantation of a managerial model with emphasis on knowledge.

According to Davenport \& Prusak (1999 p. 2), "Data is a set of discrete, objective facts about events. In an organizational context, data is more usefully described as structured records of transactions.” Thus, based on these authors, what it is understood regarding data is that, in itself, it has little importance, because it does not disclose the true meaning of what it represents and describes only part of what truly is, for whom interprets it and it does not provide previously a judgment, nor 
any sustainable base to act; thus, data is considered the essential raw material for creating information. They define information as a message that aims at shaping the person who receives it, thereby affecting their judgment or insight. For Nonaka \& Takeuchi (1997, p. 64), "information provides a new point of view to the interpretation of events or objectives, what makes visible meanings which were invisible before or it provides unexpected connections". Within this spectrum, information is a flow of messages, while knowledge is created by this very flow of information, anchored in the beliefs and commitments of its detainer.

For Sveiby (1998, p. 48) "all interpretation of information is based on experience, context and situations and contains nuances of the emotions. Thus, each interpretation is only for each individual”. According to Nonaka \& Takeuchi (1997, p. 64) "information is a material way necessary to extract and to build knowledge”. For Linke (2001, p. 21), "information kept to oneself, internalized and unexchanged can be considered the same as nothing, because in not being worked, known by the other individuals, they fail to generate new knowledge”. Knowledge is defined by Davenport \& Prusak (1999), as a mixture of condensed experience, values and information, which provides a structure for evaluation and incorporation of new experiences and information. For Nonaka \& Takeuchi (1997 p. 63) "knowledge is a dynamic human process to justify the personal belief regarding to the truth".

After the contextualization of these concepts, it is relevant to know the two main types of knowledge, that is, explicit knowledge and tacit knowledge, already mentioned by Polanyi apud Nonaka \& Takeuchi (1997).

\subsection{Types of knowledge}

In the organizations, many data and information are lost, due to non-comprehension on the part of their managers and collaborators of the difference between the many types of knowledge, making it difficult; thus, there is a relevance to create an organizational memory (LINKE, 2001).

There are two types of knowledge, high- lighted by Nonaka e Takeuchi (1997, p. 7): a) The explicit knowledge, that can be expressed in words and numbers, and easily communicated and shared under the form of raw data, scientific formulas, codified procedures or universal principles. b) The tacit knowledge, on the contrary, is highly personal and difficult to formalize, what makes it difficult to be transmitted and shared with others. The tacit knowledge is deeply rooted in the actions and in the experiences of an individual, as well as in their emotions, values or ideals.

Nonaka \& Takeuchi (1997) go on affirming that, in order for the tacit knowledge to be formalized in organizations, it will have to be converted into words or numbers, that any one can understand; so that it is precisely during the time when this conversion occurs from tacit to explicit and, again in tacit, that the organizational knowledge is created. In the words of authors Krogh; Ichijo \& Nonaka (2001, p. 15), "to admit the value of the tacit knowledge or discovering how to use it is the main challenge of a creative knowledge company, demanding open conversations and good personal relationships - that is, the qualification for knowledge”.

\subsection{Knowledge creation and the four knowledge conversion patterns}

The process of knowledge creation is based on the interaction between the tacit knowledge and the explicit knowledge. Nonaka \& Takeuchi (1997) call this process knowledge conversion, and present four ways of knowledge conversion that constitute the heart of the process of knowledge creation as a whole.

These ways of knowledge conversion are: socialization, externalization, combination and internalization. Their respective definitions are: a) Socialization: conversion of tacit knowledge in tacit knowledge, that it is linked to the theories of group processes and the organizational culture. It can be learned or taught by observing, imitating, practicing, that is, by sharing experiences, that can be acquired, observed in met, in which the mutual confidence can be extended among the participants, which is essential to experience exchange. b) Exter- 
nalization: conversion of tacit knowledge in explicit knowledge. Through this process of conversion, tacit knowledge is transformed into explicit knowledge by means of metaphors, analogies, concepts, hypotheses or models. Externalization is the key to create knowledge, because it creates new and explicit concepts from tacit knowledge. c) Combination: conversion of explicit knowledge in explicit one, which is rooted in processing of information. In this form of knowledge conversion, the combination of different sets of explicit knowledge are used, as: meetings, documents, telephonic talks, etc can lead to new knowledge. d) Internalization: conversion of the explicit knowledge in tacit knowledge, this one closely linked to organizational learning. This type of conversion is related to "learning by making”, when the explicit knowledge is incorporated turning it into tacit.

According to Linke (2001) there is no such a thing as the organizational knowledge by itself, for this knowledge is the addition of knowledge of the individuals, that take part in the organization, being result of a continuous and dynamic interaction between the tacit knowledge and the explicit knowledge, still, with the inclusion of technology, to allot it easier, and not to replace its human origins.

In addition, in the context of managing the organization, based on the principles of knowledge management, it is relevant to analyze the explicit knowledge and the tacit knowledge, and then, the process of their conversion, which imply seriously in using this managerial tool.

\subsection{Knowledge management}

From the 1990s, Terra (2005) asserts that "the pro-active knowledge management acquires a leading role for the competitiveness of companies, as well as of countries.” The author goes on, saying that the " knowledge management presents some challenges, and that these challenges are guided especially by three forces: the enormous volumes of information that are being created, stored and distributed currently; the incredible speed that the content of knowledge is changing; and the continuous transformation of the workplace.”
Nisembaum apud Costa \& Gouvinhas (2004) defines $\mathrm{KM}$ as being the process through which the generation, the storage and sharing of valuable information, insights and experience is supported, inside and between communities of people and organizations with similar interests and necessities. Thus, running an organization which is based on the principles of knowledge management is a simple task and has already been explored for a long time, as affirm Davenport \& Prusak (1999, p. 196), when they say that: KM is based on existing resources, which the organization can already be counting on - good information system management, organizational change management and good practice in human resources management. If you have a good library, a textual database system or even efficient educational programs, probably your company is already making something that can be called knowledge management. This idea is corroborated by Sveiby (1998), when he defines KM as a competitive strategic tool, resistant to the buzz word of operational efficiency and capable of taking advantage of existing resources in the company itself, providing the employment of best practice.

According to Terra (2001), KM implies, necessarily, to develop abilities interrelated in the strategic, to organize and individual plans; to accelerate competitive value new knowledge generation; to find out intellectual capital and knowledge already existing in the company; to generalize new revenues based on reusing existing intellectual knowledge / capital in the company; to protect the existing intellectual capital in the company; to improve the decision making process at managerial, production and front line levels of the company; to reduce costs and redoing the job. Besides this, confronting these challenges, Costa \& Gouvinhas (2004) affirm that mapping the processes is a foundation for all and any work of knowledge management, for a company needs to know the way it works, that is, as its operations, its businesses and its activities are carried out.

Within this KM spectrum, the importance of organizations to implant innovative strategies, searching competitive advantages, is verified. Terra (2000) affirms that KM must be related to the seven 
dimensions that evaluate the existence of action, of values, of rules and of compatible mechanisms with the implantation of the systemic process of management that involves three different levels of managerial practice: the strategic, the organizational and the structural ones. The seven dimensions of KM are: Dimension 1 - Strategic factors and the role of the top management team; Dimension 2 - Culture and Organizational Values; Dimension 3 - Organizational Structure; Dimension 4 - Human resources management; Dimension 5 - Information Systems; Dimension 6 - Result Measurement; Dimension 7 - Learning with the environment.

In the present work, dimension 3 will be approached - Organizational Structure, that is directly tied to the objective of the proposed study.

\section{Organizational structure}

The current context is characterized by accelerated changes, in markets, in technologies and in organizational structures, and the capacity to generate and to absorb innovations is considered crucial, in order to become organizations competitive.

For Terra (2000, p. 115), "the strict bureaucratic model of organization is becoming more and more inadequate to face the current challenges imposed to companies". Those authors affirm the bureaucratic companies are found, in general, in relatively steady environments, while those that are breaking with the bureaucratic paradigm, are found in more dynamic sectors and in more intensive in knowledge. Terra (2000) presents two main groups of theoretical thinking and of practical action, in the companies, in terms of implantation of innovative organizations, which are now presented: Organizational Structures, that are above the hierarchicbureaucratic structure: admitting that bureaucracy does not generate creativity, but it is adequate for knowledge accumulation, and that the organization involving task force, although providing knowledge creation, does not make its transference to the organization easier, some companies have worked on similar solutions that combine these types of structure.
Organizational Structures that look for breaking with the hierarchic-bureaucratic tradition: These new forms have the following characteristics: work in team; leadership changes according to the needs of projects; more delegation of responsibilities for getting in touch with customers; reduction of the hierarchy to the minimum possible; teams or work units have a wide array of responsibilities; work teams are supported by intelligent information systems that guarantee the capture, codification, transference and fast access to knowledge accumulated by the company; information and training must be provided just-in-time to perform; the systems for evaluation of employees take into account the opinion of all the people with whom each individual worked.

According to Nonaka \& Takeuchi (1997), the dominant models of managerial process, those which were implanted before the sprouting of $\mathrm{KM}$, are: the top-down model and the bottom-up model, both inefficient as to stimulating the necessary dynamic interaction to create organizational knowledge. The model considered by the above-mentioned authors, called middle-up-down, is superior, for the creation of knowledge, in relation to the traditional models, because it places the average-leveled manager in the center of knowledge management and redefines the role of the upper management and the employees of the front line. Top-down management is the classic hierarchic model, having its roots in Max Weber and Frederick Taylor, using the division of work, in which the upper management creates the basic concepts, so that the inferior levels can implement them. As for the bottom-up management, it is basically a top-down management reflected in the mirror, considering that the hierarchy and the division of work give place to autonomy, with knowledge being to a large extent controlled in the base. This organization has a format of few hierarchic levels, where managers give few orders and instructions, but serve as sponsors of the employees in the front line. This model is well-applied at 3M, whose basic principles are autonomy and enterprising spirit, translated into practices such as: absence of excessive planning; reduced paper use; acceptance of errors as something normal; regular border crossing; 
encouragement for initiative taking; flow of ideas from bottom to top; minimum interference of the superior levels; incapacity of the superior levels to defeat an idea and maintenance of a flat and small organizational structure (LINKE, 2001).

As to these first two models, top-down is adequate to deal with explicit knowledge, but it does not serve for knowledge creation, because it ignores the development of tacit knowledge, being able to occur the destination alignment of some managers with the company's destination. The bottom-up model, on its turn, is adequate to deal with tacit knowledge, but its emphasis on autonomy makes it difficult to create, to disseminate and to share knowledge within the organization (NONAKA e TAKEUCHI, 1997).

Considering that in the two presented models, middle management does not appear, because it only processes information, not to create new knowledge, Nonaka \& Takeuchi (1997), according to their studies, in Japanese companies, raised the third alternative, to manage and to create knowledge, that is, the middle-up-down model. According to Nonaka \& Takeuchi (1997, p.147), "in the middleup-down model, the upper management creates a vision, a dream, while the middle management develops more concrete concepts than the employees of the front line can understand and implement. The mid-level managers try to solve the contradiction between what the upper management hopes to create and what really exists in the real world". It is observed that the communication between all the hierarchic levels is fundamental, with the middle-up-down model, in the opinion of Nonaka \& Takeuchi, the one that better plays this role, since it has a responsible for operating the connection between the top and the base of the pyramid.

\section{Case: “Alpha” company}

\subsection{Company}

The “Alpha” company was established in the late 1980s, in Ponta Grossa, Paraná, where it began its activities. Its production consisted of furniture in steel, such as closets, wardrobes and file cabinets for offices, bookshelves and shelves of several models and measures. In 1992, it incorporated its branch factory of vaults in steel; in 1998, a new segment was opened, with furniture manufacturing, in steel, for supermarkets and pharmacies. Its production area occupies an area of around 50,000 $\mathrm{m}^{2}$, with a constructed area of $20.000 \mathrm{~m}^{2}$, employing $305 \mathrm{em}$ ployees directly. It processes currently around 600 tons of steel, monthly, in many types of products, what makes it one of the biggest companies in Brazil, in this field. (PACHECO apud RASPS, 2005).

\subsection{Presentation and data analysis}

It was verified, in the data collection, that in the "Alpha" company, there is not a constant use of multidiscipline and formal teams that are above the traditional hierarchic formal structure, as well as they do not use temporary teams, nor dedicate to innovative projects. Terra (2000) affirms that one of the characteristics of the organizational structures that look for breaking with the hierarchicbureaucratic tradition is the team work. However, the metallurgic industry must insert multidiscipline team working, in managerial practices, searching for a bigger agility, and reacting to the changes in the organizational environment.

It was observed that reorganizations occur. Thus, in accordance with the demand, sectors and employees are dynamically relocated with no effective control, according to what was researched, searching for adapting to the competitive environment. In the words of the interviewee, "the decisions are only made by the administration and at the upper levels, due to low scholarship level of the employees”. Within this context, a top-down organizational structure is evidenced. For Nonaka \& Takeuchi (1997), top-down management is the classic hierarchic model, in which the upper management creates the basic concepts, so that the inferior levels can implement them. However, this management is inefficient in stimulating the necessary dynamic interaction to create the organizational knowledge. 


\section{Final considerations}

In conclusion, in the researched company, reorganizations occur, aiming to adapt itself to a competitive environment. This flexibility, on its turn, is characterized as a KM element, within the scope of the organizational structure.

However, for the company in study, to implant a model of practical KM, in its managerial practice, it must strengthen other elements of the organizational structure, such as team work, to delegate responsibilities, to search for implanting a more flexible organizational structure, in order to be more agile, and, thus, adjusting the organization to the new characteristics of the market.

\section{REFERENCES}

COSTA, P. E. C.; GOUVINHAS, R. P. Gestão do conhecimento: quebrando o paradigma cultural para motivar o compartilhamento do conhecimento dentro das organizações. In: ENCONTRO NACIONAL DE ENGENHARIA DE PRODUÇÃO, 24, 2004, Florianópolis. Anais... ENEGEP: 2004, 1 CD-ROM.

DAVENPORT, T. H.; PRUSAK, L. Conhecimento empresarial. Rio de Janeiro: Campus, 1999.

KROGH, G.V.; ICHIJO, K.; NONAKA, I. Facilitando a criação de conhecimento: reinventando a empresa com o poder da inovação contínua. Rio de Janeiro: Campus, 2001. p. 350 .

LIMA, L. F. (Des)emprego tecnológico na indústria metalúrgica: estudo de caso sobre a W3 Indústria Metalúrgica Ltda., Ponta Grossa (PR). Ponta Grossa, 2005. 140 p. Dissertação (Mestrado em Ciências Sociais Aplicadas). Universidade Estadual de Ponta Grossa - UEPG.

LINKE, J. C. A gestão do conhecimento como ferramenta de desenvolvimento das empresas da indústria moveleira da região de São Bento do Sul - SC. Florianópolis, 2001. 119 p. Dissertação (Mestrado em Engenharia de Produção). Universidade Federal de Santa Catarina - UFSC.

MÜLLER, F. M.; GRINGS, R. C. Gestão do Conhecimento mediada por tecnologia da informação. In: ENCONTRO NACIONAL DE ENGENHARIA DE PRODUÇÃO, 23, 2003, Ouro Preto. Anais... ENEGEP: 2003, 1CD-ROM.

NONAKA, I.; TAKEUCHI, H. Criação de conhecimento na empresa. Rio de Janeiro: Campus, 1997. 358 p.

SVEIBY, Karl E. A nova riqueza das organizações. Rio de Janeiro: Campus, 1998. 261 p.

TERRA, José Claúdio C. Gestão do conhecimento: o grande desafio empresarial. São Paulo: Negócio Editora, 2000. 283 p.

TERRA, José Claúdio C. Fortalecendo cadeias produtivas através de portais do conhecimento. Disponível em: http:// www.terraforum.com.br. Acesso em: 17 abril 2005. 